\title{
DETERMINANTS OF INDONESIAN CONVENTIONAL AND ISLAMIC BANK DEPOSITOR TRUST DURING THE COVID-19 PANDEMIC
}

\author{
Eko Fajar Cahyono ${ }^{1}$, Lina Nugraha Rani ${ }^{2}$ and M. Fariz Fadillah Mardianto ${ }^{3}$ \\ 1,2 Faculty of Economics and Business, Universitas Airlangga, Indonesia \\ ekofajarc@feb.unair.ac.id, linanugraha@feb.unair.ac.id \\ ${ }^{3}$ Faculty of Science and Technology, Universitas Airlangga, Indonesia \\ m.fariz.fadillah.m@fst.unair.ac.id
}

\begin{abstract}
Depositor trust plays an essential role in the banking sector. The main objective of this study is to test several factors that significantly affect depositors' confidence in conventional and Islamic banks in Indonesia during the COVID-19 pandemic. We conducted qualitative research with a sample of 217 customers who had a minimum of two bank accounts, one conventional, and one Islamic. In a questionnaire, customers were asked their opinions related to indicators of the variables studied, such as depositor trust, and their perceptions of inflation, conventional bank interest, the equivalent yield rate of Islamic banks, and industry perception Productivity Index. The results of the questionnaire were analysed using the partial least squares (PLS) method. The PLS analysis results show that the indicators related to conventional bank interest and the equivalent yield rate of Islamic banks significantly affected depositors' trust and hands. In other words, customers were influenced when making bank deposits by the factors related to conventional bank interest and the equivalent yield rate of Islamic banks. The external aspect of the industrial production index based on the PLS test had a significant effect on depositors' trust in both types of bank. In contrast, the external factor of inflation did not significantly affect depositors' trust in either conventional or Islamic banks. Therefore, based on the PLS-SEM results, conclusions can be drawn regarding the factors influencing depositor trust.
\end{abstract}

Keywords: Depositor trust, Depositor funds, Macroeconomic conditions, PLS-SEM. JEL classification: C1; C5; E2; E4.

\author{
Article history: \\ Received : October 7, 2020 \\ Revised : February 16, 2021 \\ Accepted : March 4, 2021 \\ Available online : March 31, 2021
}

https://doi.org/ 10.21098/jimf.v7i1.1352 


\section{INTRODUCTION}

\subsection{Background}

The coronavirus disease (COVID-19) was confirmed to have started in Wuhan, China, in December 2019. It has spread to almost all countries, including Indonesia. The World Health Organization (WHO) officially designated it as a pandemic in March 2020, and as of July 25, 2020, WHO reported that Indonesia had recorded 94,000 positive cases and 4,600 deaths (WHO, 2020).

Based on data from the National Task Force for the Acceleration of the Handling of COVID 19, confirmed that positive cases of the disease were still experiencing a significant increase every day. As of September 23, 2020, the number of confirmed positive cases was 257,338, and active case data was 59,453 cases, while 187,958 patients had recovered, and with a death toll 9,977 (Task Force for the Acceleration of the Handling COVID-19, 2020).

Rahman, Kusuma \& Arfyanto (2020) projected the worst possible systemic impact of COVID-19 in Indonesia as a decline in the economic growth rate of 1-4\% and an increase in the poverty rate from $9.7 \%$ to $12.4 \%$ by the end of 2020 . The systemic impact of COVID-19 has led to weak economic activity among the public. One example of this is the sluggish turnover of deposits from financial institutions due to large-scale withdrawals of funds by customers to meet their needs during the pandemic. As a result, there has been chaos in the banking system or economy. Based on data from the Indonesian Central Statistics Agency (BPS), the pandemic has caused Indonesia's economic growth rate to fall to $2.97 \%$, before, it had reached an excellent level of $5.01 \%$. When the global financial crisis occurred in 2008, the stability of its financial system showed that Indonesia could survive at a rate of economic growth of $4.63 \%$ (Ascarya, 2020).

Hidayat, Farooq, Nastuion \& Sari (2020) state that there has been an impact of COVID-19 on Islamic banks. As a result of the pandemic, many micro, small, and medium enterprises (MSMEs) have gone out of business or are losing money. Consequently, this impacts the financial industry, and institutions such as banks are at risk of bad credit or default.

According to Sukmana, Indrawan \& Ajija (2020), the condition of Islamic banking in Indonesia before the COVID-19 outbreak tended to be stable. Data up to January 2020 show sufficient indicators; for example, a capital adequacy ratio (CAR) of $20.27 \%$ and return on assets (ROA) of $1.88 \%$ for Islamic commercial banks and $2.44 \%$ for Islamic business units. However, based on Indonesia Financial Services Authorities Banking Statistics, in April 2020 Islamic commercial bank performance had declined, with CAR recording a level $20.47 \%$, ROA of $1.5 \%$, and NPF a score of $3.41 \%$ (OJK, 2020).

As intermediary institutions in the financial market, banks play a significant role in mobilising funds from savers and providing funds for investment, especially in the real sector. Banks fulfil this role when they attempt to link institutions or individuals with excess or surplus money to those with a deficit or lack of funds (Onyiriuba, 2016).

Kurlat (2019) provides strong evidence that the deposit/deposit gap will be high if interest rates are high. The banking sector has free entry and exit characteristics, as well as high fixed costs. Moreover, this implies that an increase in inflation will encourage existing resources to look for more profits. This condition is a 
significant component of inflation, affecting monetary policy in two ways. While this is taking place, Maulayati, Bahril \& Herianingrum (2020) claimed forecasted economic situations with the industrial production index (IPI) and real interest rates on savings positively impacted Islamic banks' depository funds.

Alamsyah, Ariefianto, Saheruddin, Wardono \& Trinugroho (2020) found that depositors' trust in Indonesia consisted of 992 depositors. Depositors also have more confidence when there is adequate information from the government, or the government provides complete, official, and clear communication.

Based on the facts, we have determined the concept of the novelty of this research. The study combines various internal and external factors that influence the level of depositors' trust in banks. Internal factors such as interest rates and the equivalent yield rate of Islamic banks for Islamic banks and assets affect depositor trust, as do specific external factors such as macroeconomic conditions, inflation, and the industrial production index. The originality of the study method lies in the type of data used; namely, the analysis is based on the partial least squares structural equation modeling (PLS-SEM) approach with qualitative data. The variables needed for qualitative research were adjusted to the variables used in quantitative research. The PLS-SEM model is a soft modeling technique that does not require many measurement scales, a large sample size, or residual distributions (Monecke \& Leisch, 2012).

In the case of banking, the PLS-SEM approach is often used; for example, Avkiran and Ringle (2018) employed it to model bank micro and macroeconomic level. The microeconomic level included customer service quality, managerial effectiveness, and perception of market leadership, while the macroeconomic level included contagion of systemic risk from one financial sector to another, herd behaviour among fund managers, and risk tolerance in financial markets. Serrano-Cinca, Gutiérrez-Nieto \& Molinero (2011) prediction bankruptcy based on a combination of PLS-SEM and discriminant analysis. In addition, Gadzo, Kportorgbi \& Gatsi (2018) investigated the effect of credit risk and operational risk on universal bank financial performance in Ghana.

\subsection{Objective}

The purpose of this research is to determine whether there is an influence of internal and external factors on customer confidence in saving in conventional and Islamic banks related to the COVID-19 pandemic, qualitatively based on the PLS method using primary data.

The paper begins with an introductory section consisting of the background and objectives. The second section is the literature review, focusing on theoretical studies and analysis of previous research. The third section describes the research method, the selected data and analysis methods, while the following section presents the results and discussion of the research results, with comparison to previous research. The last section comprises the conclusion and recommendations based on the research results. 


\section{LITERATURE REVIEW}

\subsection{Background Theory}

\section{a. Trust}

Trust in a company is an attitude to admit someone's truth or something without sufficient evidence and the ability to follow someone or according to trust values without requiring evidence (Park, 2020). Trust will have positive outcomes for companies or institutions. One way to measure trust in a financial institution is to determine the willingness of its customers to make transactions with it and buy its products (Park, 2020; Osili \& Paulson, 2014). Osili \& Paulson (2014) argues that financial decisions are influenced by trust in financial institutions. Such decisions are based on how consumers of financial institutions undertake their economic activities and engage with the institutions.

Kartika, Firdaus \& Najib (2019) state that customers' trust in Islamic banks provides a moral obligation for banks to maintain such trust and increase customer loyalty. This loyalty is very important for banks, as loyal customers will find it easier to buy and trust banking products. This condition is profitable and supports increased banking operations and profitability with low marketing costs. In Islamic financial institutions, customer trust is shown through institutional operations that focus on developing the sharia compliance of products and business strategies, CSR and risk management. There are several customer trust indicators in Islamic banks, consisting of sharia compliance based on the Council of Indonesian Ulama (MUI); legal compliance with the Central Bank (Bank Indonesia); safety based on the Central Bank and Financial Authorities Services; concern with social funds such as zakat; and and CSR. Their research can be translated to that depositors' trust is the most important issue in the sustainability of banking operations. This is because banks are intermediary institutions that collect funds from depositors and invest them in loans or financing. Banks pay great attention to the principle of prudence in collecting funds and investments in the form of credit or financing assets to improve their financial performance, which provides benefits for depositors and the banks themselves. Banks maintain the trust of depositors and their operations, especially by complying with the rules of financial system stability issued by the Central Bank (Bank Indonesia), the Financial Authorities Services, Indonesia Deposit Insurance Corporation and the Indonesian Ministry of Finance.

Schoors, Semenova \& Zubanov (2019) state that an economic condition occurs with a high level of uncertainty such as a crisis. This will encourage investors to place their funds in assets that are considered more familiar, even if they have to face lower income or high-risk disclosure, which can also occur in the banking sector. Investors in banks, namely depositors, will face bank risks in times of crisis, and they will further increase their trust by reducing their discipline or sensitivity to changes in deposit interest rates and their growth in trusted banks.

This study measures internal and external banking factors that affect bank depositor trust and bank trust. Internal factors include third party funds and the condition of the bank, while external factors include deposit insurance corporations, macroeconomic conditions (unemployment), crisis situations, Central Bank independence and religion. The literature on the influence of internal and external factors on bank depositor trust and bank trust is discussed below. 


\section{b. Depositor Trust and Internal Factors}

1. Relationship between Depositor Trust and Bank Third Party Funds

Depositors are critical stakeholders in banks. Jin, Kanagaretnam \& Wang (2020) state that one financing source for banks is customer deposits. They found strong evidence of a relationship between social trust as measured using social capital on customer bank deposits. Thet also demonstrated that banks with conservative mangers and those located in sectors of society with higher social capital had higher customer deposits than banks with non-conservative managers and those situated in communities with capital lower social. The choice of bank will determine customers' trust. Therefore, the first hypothesis proposed is:

H1. There is a significant relationship between Depositor Trust and Bank's Third Party Funds.

\section{Relationship between Bank Depositor Trust and Bank Condition}

Bank stigma can be a major factor for depositors. Anbil (2018) studied the nature of such stigma and showed that the respondents considered that news about banks receiving liquidity assistance was very bad. This information reflected the weakness of the banks' financial condition. If the stigma towards a bank is strong, it will encourage customers to withdraw funds from the bank.

Fungáčová, Hasan \& Weill (2019) highlight that depositors exposed to information and news will have more confidence in banks than those rarely exposed to lead. Van Esterik-Plasmeijer and Van Raaij (2017) state that depositors' trust is influenced by bank competence. This includes the bank's ability to undertake its functions, and the competence and integrity of the human resources in the company. Competence is also reflected in the bank's ability to innovate by providing services to customers and stakeholders and how it treats its customers. Therefore, the second hypothesis is:

H2. There is a significant relationship between Bank Depositor Trust and Bank Condition.

\section{c. Depositor Trust and External Factors}

1. Relationship between Bank Depositor Trust and the Existence of a Deposit Insurance Corporation

Trust in banks is closely related to trust in the financial system as a whole. This system includes the financial industry and industry regulators, such as the Central Bank and the Deposit Insurance Corporation (Fungáčová et al., 2019). The third hypothesis posited is therefore:

H3. There is a significant relationship between Bank Depositor Trust and the existence of a Deposit Insurance Corporation.

\section{Relationship between Bank Trust and Macroeconomic Conditions (Unemployment)}

Stevenson and Wolfers (2011) investigated how the unemployment rate affected the level of bank confidence in the United States. They found that it had a significant negative impact on institutional bank trust. Park (2020) found that a 
deposit insurance corporation in Korea could influence stakeholders' trust in the banking sector, such as that of managers, investors, and customers.

H4. There is a significant relationship between Bank Trust and Macroeconomic Conditions (Unemployment).

3. Relationship between Bank Depositor Trust and Central Bank Independence Berggren, Daunfeldt \& Hellström (2014) provide evidence that there is a strong correlation between depositor trust and the perception of central bank independence in various countries. Their study was conducted with data from 149 countries. The freedom of the Central Bank that is strong that economic reform has been carried out gives rise to depositor confidence. Therefore, the fifth hypothesis is:

H5. There is a significant relationship between Bank Depositor Trust and Central Bank Independence.

\section{Relationship between Bank Depositor Trust and Religion}

The value of religion for many people is very important. Religious teachings are also influential in providing guidelines for daily life, with the economy being no exception. Fungáčová et al. (2019) investigated how religious teachings affect bank customer trust. They researched customers of various religions, such as Protestantism, Catholicism, Islam, Hinduism, Orthodox, Buddhism, together with those with no religion. They concluded that Catholics do not trust banks because they prohibit interest, and for Muslims, there is also the principle of refusing interest. In contrast, Protestants and Hindus have high confidence in banks. Therefore, the sixth hypothesis is:

H6. There is a significant relationship between Bank Depositor Trust and Religion.

\section{d. Depositor Trust and Pandemic Situations}

\section{Relationship between Bank Trust and Crisis Situations}

Knell and Stix (2015) asked respondents in Austria about their trust in banks in a financial crisis situation. The results show that the Austrian public's belief level tends to decrease because there is a greater risk that banks will face during the financial crisis. Sapienza and Zingales (2012) also studied the effect of the 2008 financial crisis on depositors' trust in the United States. Using data from more than 1000 households sourced from Social Science Research Solution data, they made friends that there had been a decrease in depositors' trust in banks. Therefore, the seventh hypothesis is:

H7. There is a significant relationship between Bank Trust and Crisis Situations.

\section{Buffer-Stock Theory of Savings}

Ünvan and Yakubu (2020) discuss the buffer-stock theory of savings, which proposes that individuals who hold assets have the primary aim to protect their consumption in the face of conditions of unpredictable fluctuation in their income. The theory assumes that customers will become impatient and cautious when faced with illnesses related to income uncertainty. They will be impatient because they are using loans with future income to meet current consumption, and they are also cautious because they have preventive motives. Due to uncertain conditions, customers began to reduce their level of consumption to save. It can be concluded 
that individuals prefer to keep when income increases or the level of consumption decreases under bad conditions.

\subsection{Previous Studies}

Alamsyah et al. (2020) argue that banks play an important role in the economy because banking is an aggregate investment, namely the distribution of fundraising in bank saving products for investment in loans. Based on this, depositors play an important role in the sustainability of banking operations, so their trust is the main focus of the banking sector. Banks are very exposed to the risk of liquidity shortages if depositors make large withdrawals at the same time. They will experience difficulties in providing cash withdrawals to depositors because their funds are channeled in investment credit, in which loan refunds have been arranged according to the credit contract and cannot be immediately returned to borrowers. This shows the important role of depositors in the effectiveness and sustainability of banking operations.

In the study of Alamsyah et al. (2020), 992 retail depositors were surveyed to assess their level of trust in banks (TIB), trust in the banking industry, and a financial safety net (TBF), and depositors' trust index, where the three variables become dependent variables. The determinants were measured on the three dependent variables using the ordinary least squares (OLS) regressions method with robust standard errors. The independent variables consisted of Newspapers, Online Media, Television, Social Media, Age, Family, Gov't, Size_Deposits, Experts, Religious, Economic, Culture, Risk-Taking, Material, Social, Gender, Education, dummy_java and Big4. The research results show that trust in individual banks by depositors is more important than trust in banks overall. The results based on the depositor group showed low trust amongst women, and older and educated depositors. Overall, their research results show that depositor trust is influenced by religious and economic values, risk-taking behaviour, and the government's role in supporting banking. Important role of deposit insurance in providing financial literacy for depositors and the public avoid erosion of market discipline.

Sapienza and Zingales (2012) surveyed 1034 households in the United States by telephone, asking questions about how many of the respondents trusted a particular type of institution or person, including bankers, banks, governments, large companies, market capitalists, and brokers. They were asked to provide a trust ranking from 1, 'I do not trust at all', to 5, 'I trust completely' in answering several questions as a proxy for risk. One of the aims of the survey was to produce an average ranking of several institutions, such as the stock market, brokers, large corporations, the government, bankers, banks and other people. The survey results show that the level of trust in institutions ranged from a minimum of 2.13 (achieved by the stock market) to 3.33 (achieved by other people). As a whole, it was concluded that at the time of the global financial crisis in 2008 there was a very small decrease in trust in the financial institution sector. This was related to the desire to withdraw funds by depositors who had invested in the capital market and had savings, and the role of government intervention, especially in the capital market. Almost $40 \%$ of respondents experienced a fall in trust. 
Jansen, Mosch \& van der Cruijsen (2015) found that trust in financial institutions could be strongly affected in times of crisis. Their paper adds to this existing body of knowledge by outlining specific factors that have a strong link to overall trust in banks. The main reason why members of the Dutch general public would lose faith in banks is related to large bonuses. To some extent, and depending on the survey year, adverse media reports, a drop in share prices, and opaque product information could also be essential factors. Government intervention, in particular through nationalisations, was not a significant reason for losing trust. Bank bailouts lead to less concern about government intervention, while bank failure experience results in more considerable concern regarding bonuses. The public's close link of trust to executive compensation is the essential issue in current debates. Jansen et al. (2015) show how the general public in the Netherlands makes a close link between bonuses and trust, notwithstanding the technicalities or subtleties surrounding academic discourse or policy discussions on executive compensation.

\section{METHODOLOGY}

\subsection{Data}

The primary data were obtained by surveying customers with at least one conventional bank account and one Islamic bank account. The survey was conducted by distributing questionnaires online via the Google Forms platform to eligible respondents. The questions asked related to the quantitative research variables, namely interest rates for conventional banks, the equivalent yield rate for Islamic banks, IPI, and inflation, together with questions related to deposits and the motivation to become a conventional bank customer. At the same time, Islamic banks associated with the COVID-19 pandemic conditions used population assumptions based on an official statement from the Indonesian Financial Services Authority (OJK) in October 2019 that the number of customers of Islamic banks in Indonesia was 31.89 million (Situmorang, 2019).

In this research, 217 respondents participated virtually in the questionnaire, with a research period of around a month during August 2020 in Indonesia. This number approximates to the recommendations of Chin (2003) and Hair, Sarstedt, Ringle \& Gudergan (2017), who state that an ideal sample size is at least ten times the number of indicators, or $10 \times 20$. The results of the questionnaire were used for qualitative research using PLS.

\subsection{Model Development}

For the PLS-SEM development, all the variables were informed because the development was related to determination of the variables. The latent variable and indicators are presented in Table 2 for conventional banks and Table $\mathbf{3}$ for Islamic banks, with the general questions shown in Table 1. Qualitative variables are often referred to as latent variables. 
Table 1.

General Variables

\begin{tabular}{lcc}
\hline No. & Variable & Category \\
\hline \multirow{2}{*}{ G. } & Gender & Male \\
& & Female \\
\hline \multirow{2}{*}{ 2. } & \multirow{2}{*}{ Age } & A. $<20$ \\
& & B. $20-<25$ \\
& & C. $25-<35$ \\
& D. $35-50$ \\
\hline
\end{tabular}

Highest Level of
Education

5. Income Level

Occupation

I. Farmer, R

7. Product Ownership

Reasons for Becoming
a Depositor at
Conventional and
Islamic Banks

\section{A. SHS/Equivalent}

B. D1 - D3 (Diploma) /Equivalent

C. S1(Bachelor) /Equivalent

D. S2 or S3 (Postgraduate)

A. Under Rp 2.500.000,00

B. Rp $2.500 .000,00-\operatorname{Rp} 4.999 .999,00$

C. Rp 5.000.000,00 - Rp 9.999.999,00

D. Rp 10.000.000,00 - Rp 19.999.999,00

E. Rp 20.000.000,00 or more.

A. Civil servant. non-professional

B. BUMN, non-professional

C. Private worker, non-professional

D. Civil servant

E. BUMN

F. Private worker

G. Army/Police

H. Enterpriser

J. Others

Savings

Deposit

Giro

Debit Card

Credit Card

Payroll

Incentive Payments

Loan Installment Payment

ing (Hajj, Umrah, Education, Marriage, Home

Renovation, etc.)

Fund Management Principles

Bank Reputation

Attractive Interest Rate

Fund Saving Security

Guaranteed LPS

Others 
Table 2.

Conventional Bank Variables and Indicators

\begin{tabular}{|c|c|c|}
\hline No & Variable & Indicator \\
\hline \multirow{8}{*}{1.} & \multirow{8}{*}{$\begin{array}{l}\text { Conventional Bank } \\
\text { Depositor } \\
\text { Trust } \\
\left(\eta_{11}\right)\end{array}$} & $\begin{array}{c}y_{1 c} \text { (I still believe in conventional banks during the COVID-19 pandemic } \\
\text { because they have huge assets) }\end{array}$ \\
\hline & & $\begin{array}{c}y_{2 c} \text { (I still believe in conventional banks during the COVID-19 pandemic } \\
\text { because they have a good reputation) }\end{array}$ \\
\hline & & $\begin{array}{l}y_{3 c} \text { (I will still put my funds into conventional banks even though there is } \\
\text { the chance of an economic crisis during the COVID-19 pandemic) }\end{array}$ \\
\hline & & $\begin{array}{l}y_{4 c} \text { (I still believe in the reliability of conventional banks in managing my } \\
\text { business so that my funds will not be lost during the COVID-19 pandemic) }\end{array}$ \\
\hline & & $\begin{array}{l}y_{5 c} \text { (I still believe in conventional banks and the safety of my funds because } \\
\text { the Deposit Insurance Corporation has guaranteed them during the } \\
\text { COVID-19 pandemic) }\end{array}$ \\
\hline & & $\begin{array}{c}y_{6 c} \text { (I believe conventional banks have met good governance standards } \\
\text { following the Deposit Insurance Corporation's rules, so I feel my funds are } \\
\text { safe in conventional banks.) }\end{array}$ \\
\hline & & $\begin{array}{l}y_{7 c} \text { (I know that my savings in a conventional bank are safe because they } \\
\text { are guaranteed by the Deposit Insurance Corporation, including during } \\
\text { the COVID-19 pandemic) }\end{array}$ \\
\hline & & $\begin{array}{l}y_{8 c} \text { (I know that the government of the Republic of Indonesia has issued } \\
\text { policies during the COVID-19 pandemic to improve the economy, so I } \\
\text { have not withdrawn funds from a conventional bank) }\end{array}$ \\
\hline \multirow{4}{*}{2.} & \multirow{4}{*}{$\begin{array}{l}\text { Perception of } \\
\text { Interest Rate }\left(\xi_{1 c}\right)\end{array}$} & $\begin{array}{c}x_{11 c}(\mathrm{I} \text { keep my savings in a conventional bank because of the attractive } \\
\text { interest rates) }\end{array}$ \\
\hline & & $\begin{array}{c}x_{12 c} \text { (If the interest rate falls, I withdraw my savings from the conventional } \\
\text { bank) }\end{array}$ \\
\hline & & $\begin{array}{c}x_{13 c} \text { (If the interest rate is too low, I will not open a deposit account at a } \\
\text { conventional bank) }\end{array}$ \\
\hline & & $\begin{array}{c}x_{14 c} \text { (The interest rate is an important factor for me to place my funds in } \\
\text { conventional banks) }\end{array}$ \\
\hline \multirow{4}{*}{3.} & \multirow{4}{*}{$\begin{array}{l}\text { Perception of IPI } \\
\qquad\left(\xi_{2 c}\right)\end{array}$} & $\begin{array}{c}x_{21 c} \text { (I believe that a high inflation rate will affect the performance of } \\
\text { conventional banks, thus putting the security of my funds at risk) }\end{array}$ \\
\hline & & $\begin{array}{l}x_{22 c} \text { (I believe that a low inflation rate will improve the performance of } \\
\text { conventional banks provide security for my funds }\end{array}$ \\
\hline & & $\begin{array}{c}x_{23 c} \text { (If inflation is higher, then I decide to withdraw my funds from } \\
\text { conventional banks) }\end{array}$ \\
\hline & & $\begin{array}{c}x_{24 c} \text { (If inflation decreases, then I decide to save funds in a conventional } \\
\text { bank) }\end{array}$ \\
\hline \multirow{4}{*}{4.} & \multirow{4}{*}{$\begin{array}{l}\text { Perception of } \\
\text { Inflation }\left(\xi_{3 c}\right)\end{array}$} & $\begin{array}{l}x_{31 c} \text { (I believe that if the IPI level increases, then there is an indication } \\
\text { that economic conditions are better due to an increase in the average } \\
\text { production of goods from the industrial sector in Indonesia.) }\end{array}$ \\
\hline & & $\begin{array}{c}x_{32 c} \text { (I believe that if the IPI level increases, the performance of conventional } \\
\text { banks will be better, and my funds will be safer) }\end{array}$ \\
\hline & & $\begin{array}{c}x_{33 c} \text { (I will feel calm saving my funds in conventional banks when the IPI } \\
\text { indicator rises) }\end{array}$ \\
\hline & & $\begin{array}{c}x_{34 c} \text { (I will withdraw my funds from conventional banks when the IPI } \\
\text { indicator falls) }\end{array}$ \\
\hline
\end{tabular}


Table 3.

Islamic Bank Variables and Indicators

\begin{tabular}{|c|c|c|}
\hline No & Variable & Indicator \\
\hline \multirow{8}{*}{1.} & \multirow{8}{*}{$\begin{array}{l}\text { Islamic } \\
\text { Bank Depositor } \\
\text { Trust } \\
\left(\eta_{1 s}\right)\end{array}$} & $\begin{array}{c}y_{1 s} \text { (I still believe in Islamic banks during the COVID-19 pandemic because } \\
\text { they have huge assets) }\end{array}$ \\
\hline & & $\begin{array}{c}y_{2 s} \text { (I still believe in Islamic banks during the COVID-19 pandemic because } \\
\text { Islamic banks have a good reputation) }\end{array}$ \\
\hline & & $\begin{array}{c}y_{3 s} \text { (I will still put my funds in Islamic banks even though there is the chance } \\
\text { of an economic crisis during the COVID-19 pandemic) }\end{array}$ \\
\hline & & $\begin{array}{c}y_{4 s} \text { (I still believe in the reliability of Islamic banks in managing my } \\
\text { business, so my funds will not be lost during the COVID-19 pandemic.) }\end{array}$ \\
\hline & & $\begin{array}{c}y_{55} \text { (I still believe in Islamic banks and the safety of my funds because the } \\
\text { Deposit Insurance Corporation has guaranteed them during the COVID-19 } \\
\text { pandemic) }\end{array}$ \\
\hline & & $\begin{array}{l}y_{6 \mathrm{~s}} \text { (I believe that Islamic banks have met the standards of good governance } \\
\text { following the rules of the Deposit Insurance Corporation, so I feel my funds } \\
\text { are safe in conventional banks) }\end{array}$ \\
\hline & & $\begin{array}{l}y_{7 s}(\mathrm{I} \text { know that my savings in an Islamic bank are safe because they are } \\
\text { guaranteed by the Deposit Insurance Corporation, including during the } \\
\text { COVID-19 pandemic) }\end{array}$ \\
\hline & & $\begin{array}{l}y_{8 s} \text { (I know that the government of the Republic of Indonesia has issued } \\
\text { policies during the COVID-19 pandemic to improve the economy, so I have } \\
\text { not withdrawn my savings from an Islamic bank) }\end{array}$ \\
\hline \multirow{4}{*}{2.} & \multirow{4}{*}{$\begin{array}{l}\text { Perception of the } \\
\text { Equivalent Yield } \\
\text { Rate of Islamic } \\
\text { Banks } \\
\left(\xi_{1 s}\right)\end{array}$} & $\begin{array}{c}x_{11 s} \text { (I save funds in Islamic banks because of the attractive equivalence yield } \\
\text { rate) }\end{array}$ \\
\hline & & $\begin{array}{c}x_{12 s} \text { (If the equivalent yield rate of Islamic banks falls, I will withdraw my } \\
\text { savings from the bank) }\end{array}$ \\
\hline & & $\begin{array}{l}x_{13 s} \text { (If the equivalent yield rate of Islamic banks is too low, I will not open a } \\
\text { deposit account at an Islamic bank) }\end{array}$ \\
\hline & & $\begin{array}{c}x_{14 s} \text { (The equivalent yield rate of Islamic banks is an important factor for me } \\
\text { in deciding to place my funds in an Islamic bank) }\end{array}$ \\
\hline \multirow{4}{*}{3.} & \multirow{4}{*}{$\begin{array}{l}\text { Perception of IPI } \\
\qquad\left(\xi_{2 s}\right)\end{array}$} & $\begin{array}{c}x_{21 s} \text { (I believe that a high inflation rate will affect the performance of Islamic } \\
\text { banks, thus putting the security of my funds in them at risk) }\end{array}$ \\
\hline & & $\begin{array}{l}x_{22 s} \text { (I believe that a low inflation rate will improve the performance of } \\
\text { Islamic banks to and provide security for my funds }\end{array}$ \\
\hline & & $\begin{array}{l}x_{23 s} \text { (If inflation rises, then I will decide to withdraw my funds from the } \\
\text { Islamic bank) }\end{array}$ \\
\hline & & $x_{24 \mathrm{~s}}$ (If inflation falls, then I will decide to save funds in an Islamic bank) \\
\hline \multirow{4}{*}{4.} & \multirow{4}{*}{$\begin{array}{l}\text { Perception of } \\
\text { Inflation }\left(\xi_{3 s}\right)\end{array}$} & $\begin{array}{l}x_{315} \text { (I believe that if the IPI level increases, then there is an indication that } \\
\text { economic conditions are better due to an increase in the average production } \\
\text { of goods from the industrial sector in Indonesia) }\end{array}$ \\
\hline & & $\begin{array}{l}x_{325} \text { (I believe that if the IPI level increases, the performance of Islamic banks } \\
\text { will be better, and my funds will be more secure) }\end{array}$ \\
\hline & & $\begin{array}{c}x_{335} \text { (I will feel calm saving my funds in Islamic banks when the IPI indicator } \\
\text { increases) }\end{array}$ \\
\hline & & $\begin{array}{c}x_{345} \text { (I will withdraw my funds from Islamic banks when the IPI indicator } \\
\text { decreases) }\end{array}$ \\
\hline
\end{tabular}


The assessment categories ranged from (1) strongly disagree to (4) strongly agree. The use of these categories without a neutral scale was to avoid a biased score from respondents. Biased scores from respondents who become modus or majority can make sure that a conclusion (Azzara, 2010).

\subsection{Partial Least Squares Structural Equation Modeling (PLS-SEM)}

Based on Monecke and Leisch (2012), three PLS-SEM models, the inner model, the outer model, and the weight relation. The inner model shows the relationship between the latent variables, while the outer model shows the relationship between the manifest variable and the latent variable. The weight relation shows the estimated value of the latent variable.

The structural, or inner, model describes the relationship model between the latent variables formed based on substance theory. PLS-SEM is designed for a recursive model (one-way causality) so that there is a relationship between the endogenous latent variables, also called the causal chain system, in the form of equation 1:

$$
\eta_{j}=\sum_{i=1}^{j_{2}} \beta_{j i} \eta_{i}+\sum_{b=1}^{b_{1}} \gamma_{j b} \xi_{b}+\zeta_{j}
$$

where $\mathrm{j}=1,2, \ldots, j_{1}, \mathrm{i}=1,2, \ldots, j_{2}$, and $\mathrm{b}=1,2, \ldots, b_{1}$

$j_{2}$ : Number of other endogenous latent variables;

$b_{1}$ : Number of exogenous latent variables;

$\eta_{j}$ : Endogenous variable $\mathrm{j}$;

$\eta_{i}$ : Endogenous variable $\mathrm{i}$ to $\mathrm{i} \neq \mathrm{j}$;

$\beta_{j i}$ : Coefficient of the endogenous latent variable $-\mathrm{i}$ to the endogenous latent variable j;

$\gamma_{j b}$ : Coefficient of the exogenous latent variable-b to the endogenous latent variable j;

$\zeta_{j} \quad$ : Measurement error (inner residual) latent variable $\mathrm{j}$

In other PLS-SEM measurements, the measurement, or outer, model describes the relationship between the latent variables and their indicators. There are two models in the outer model: the formative and reflective indicator models (Hair et al., 2017).

\subsubsection{Parameter Estimation of PLS-SEM}

The least-squares method is used to estimate the parameters in PLS-SEM. Previous studies related to parameter estimations for PLS-SEM based on the least squares method include those of Trujillo (2009) and Ghozali \& Latan (2015).

\subsubsection{PLS-SEM Model Evaluation}

Model evaluation (goodness of fit) includes evaluation of the structural and measurement models. A review of the measurement model or outer model is conducted to assess the model's validity and reliability. Measurement models with reflective indicators can be evaluated using several methods, including: 


\section{Convergent Validity}

Convergent validity relates to the principle that the manifest variables of a construct should be highly correlated. It can be measured based on the following values:

a. Loading factor. The rule of thumb commonly used to assess convergent validity is that the loading factor value must be higher than 0.7 for confirmatory research. A loading factor value between 0.6-0.7 for explanatory research is still acceptable (Chin, 1998).

b. Average Variance Extracted (AVE). The AVE value must be greater than 0.50, which means that $50 \%$ or more of the indicator variance can be explained (Chin, 1998). The AVE calculation formula is:

$$
A V E_{j}=\frac{\sum_{i}^{k} l^{2}{ }_{j k}}{\sum_{i}^{k} l^{2}{ }_{j k}+\sum_{i}^{k} \operatorname{var}\left(\varepsilon_{j k}\right)}
$$

where var $\left(\varepsilon_{j k}\right)=1-l^{2}$ and $l^{2}{ }_{j k}=\left(y_{j}^{\prime} y_{j}\right)^{-1} y_{j}^{\prime} x_{k} ; y$ is the latent variable score; $j$ is the number of latent variables $(j=1,2, . ., 4)$; and $k$ is the number of indicator variables $(k=1,2, \ldots, 28)$.

\section{Discriminant Validity}

Discriminant validity relates to the principle that the different manifest variables should not be highly correlated. It can be measured based on the cross-loading value; the value for each variable must be $>0.7$. The latent construct predicts the block size better than the other block sizes if the construct correlation with the measurement item is more significant than the correlation with other constructs (Trujillo, 2009).

3. Reliability

A reliability test is used to measure the consistency of the instruments measuring the concepts or it can also be used to measure the viscosity of the respondents in answering the instrument. The reliability test in PLS can use composite reliability and Cronbach's alpha methods.

a. Composite reliability measures the actual reliability value of a construct and is better at estimating internal consistency. The rule of thumb for alpha or composite reliability values is that they must be greater than 0.7 , although 0.6 is acceptable (Santosa, 2018). The formula for calculating composite reliability is:

$$
\rho_{c j}=\frac{\left(\sum l_{j k}\right)^{2}}{\left(\sum l_{j k}\right)^{2}+\sum \operatorname{var}\left(\varepsilon_{j k}\right)}
$$

where $l_{j k}$ is a loading factor between indicator $k$ and latent variable $-j$ and $\operatorname{var}\left(\varepsilon_{j k}\right)$ $=1-l_{j k}^{2}$ and $l_{j k}^{2}=\left(y_{j}^{\prime} y_{j}\right)^{-1} y_{j}^{\prime} x_{k^{\prime}} y$ is the latent variable score; $j$ is the number of latent variables $(j=1,2, . ., 4)$; and $k$ is the number of indicator variables $(k=1,2, \ldots, 28)$.

b. Cronbach's alpha measures the lower limit of the reliability value of a construct. This value reflects the reliability of all the indicators in the model. The value of Cronbach's alpha must be greater than 0.7 for confirmatory research, although 0.6 is acceptable for explanatory research (Chin, 1998). 
Structural models can be evaluated using:

1. R-Square for dependent constructs

Structural models can be evaluated by observing the significance of the relationship between the constructs or latent variables. This can be seen from the path coefficient, which describes the relationship between the latent variables. The results can be obtained from the significance of the path coefficient of the t-test (critical ratio) acquired from the bootstrapping process (resampling method). Chin, cited in Ghozali \& Latan (2015), states that the criteria are value limits of $R^{2}$ in three classifications, namely $0.67,0.33$, and 0.19 , indicating substantial, moderate, and weak.

2. Prediction relevance $\left(Q^{2}\right)$

This test is conducted to measure how well the model's observation value and its parameter estimates. This technique can present cross-validation and fitting functions with the observed variables' predictions from the construct parameters. The approach was adopted by PLS using a blindfolding procedure (Ghozali \& Latan, 2015) with the formula:

$$
Q^{2}=1-\frac{S S E}{S S O}
$$

SSE is the sum of the squares of prediction error and SSO is the sum of the square errors using the mean for prediction. The value of $Q^{2}>0$ shows that the model has predictive relevance, while $Q^{2}<0$ shows that the model lacks predictive relevance. 3. Significance (two-tailed)

To determine the effect of the variables through the bootstrapping procedure. The significance value used were the $\mathrm{t}$-values of 1.65 (significance level $=10 \%$ ), 1.96 (significance level $=5 \%$ ), and 2.58 (significance level = 1\%) (Trujillo, 2009).

4. The Goodness of Fit (GoF) Index

The GoF index, developed by Tanenhaus et al. (2005), can be used to evaluate structural models and overall measurements, which can be calculated using the following formula:

$$
G o F=\sqrt{\overline{c o m} \times \bar{R}^{2}}
$$

where $\overline{c o m}$ is the average of the AVE and $\bar{R}^{2}$ is the average value of $R$-squared. The value criteria of GoF is GoF small if the value of GoF $\leq 0.1$, GoF medium if it is $0.25 \leq$ $G o F<0,36$, and $G o F$ large if the value of $G o F \geq 0,36$ (Trujillo, 2009). 


\section{RESULTS AND ANALYSIS}

\subsection{Results}

In Table 4, the demographics of the respondents are presented.

Table 4.

Respondent Demographics

\begin{tabular}{llc}
\hline No & \multicolumn{1}{c}{ Category } & Percentage \\
\hline $\mathbf{1}$ & Respondent's Age & \\
\hline & $<20$ years old & $2.12 \%$ \\
& 20 - 25 years old & $24.82 \%$ \\
& 25 -35 years old & $58.86 \%$ \\
& 35 - 50 years old & $14.18 \%$ \\
\hline $\mathbf{2}$ & Respondent's Education & \\
\hline & Senior High School & $3.68 \%$ \\
& College & $3.68 \%$ \\
Undergraduate & $37.32 \%$ \\
& Postgraduate & $55.30 \%$ \\
\hline Top Nine Repondent Occupations & \\
\hline & Professional Private Sector & $38.26 \%$ \\
Professional Government Employee & $32.14 \%$ \\
Enterpreneur & $7.14 \%$ \\
Student & $5.61 \%$ \\
State Owned Enterprise Employee & $5.10 \%$ \\
Non-professional Private Sector & $4.08 \%$ \\
Non-professional Government Employee & $3.57 \%$ \\
Lecturer & $3.06 \%$ \\
Housewife & $1.02 \%$ \\
\hline Top Six Conventional Bank Saving Motivations & \\
\hline & Payroll & $40.96 \%$ \\
Incentive Payments & $15.96 \%$ \\
Bank Reputation & $15.06 \%$ \\
Guarantee from Deposit Insurance & $14.75 \%$ \\
Financial Planning (Hajj, Umrah, Education) & $9.93 \%$ \\
Ease of Transactions & $3.31 \%$ \\
\hline & Top Seven Islamic Bank Saving Motivations & \\
\hline & Management Fund Principles/ Sharia Compliance & $33.15 \%$ \\
& Safe Deposits of Funds & $16.44 \%$ \\
Guarantee from Deposit Insurance & $15.63 \%$ \\
Bank Reputation & $13.75 \%$ \\
Payroll & $13.02 \%$ \\
Incentive Payments & $5.92 \%$ \\
Rate of Return & $1.89 \%$ \\
\hline
\end{tabular}




\subsection{PLS-SEM Results}

Modeling based on the PLS-SEM method was conducted using qualitative data to determine the factors influencing conventional and Islamic banks factors in undertaking activities related to depositor funds. These results are essential in determining the factors influencing customers' choice of conventional and Islamic banks, and whether there are similarities and differences, particularly ones associated with the COVID-19 pandemic.

\subsubsection{PLS-SEM Results Using All Variables for Conventional and Islamic Banks} The modeling of factors influencing conventional and sharia bank selection based on the PLS-SEM method was conducted by evaluating the model and the measurement model. The model structure included four latent variables for conventional banks, consisting of one endogenous latent variable and three exogenous latent ones. These can be seen in Table 2. The outer loading value results for all of the indicators are presented in Table 5.

Table 5 .

Outer Loading Values from All the Indicators for Conventional Banks

\begin{tabular}{|c|c|c|c|c|}
\hline No & Variable & Indicator & Outer Loading & Decision \\
\hline \multirow{8}{*}{1.} & \multirow{8}{*}{$\begin{array}{c}\text { Conventional Bank Depositor } \\
\text { Trust }\left(\eta_{1 c}\right)\end{array}$} & $y_{1 c}$ & 0,819 & Valid \\
\hline & & $y_{2 c}$ & 0,879 & Valid \\
\hline & & $y_{3 c}$ & 0,815 & Valid \\
\hline & & $y_{4 c}$ & 0,867 & Valid \\
\hline & & $y_{5 c}$ & 0,872 & Valid \\
\hline & & $y_{6 c}$ & 0,869 & Valid \\
\hline & & $y_{7 c}$ & 0,818 & Valid \\
\hline & & $y_{8 c}$ & 0,810 & Valid \\
\hline \multirow{4}{*}{2.} & \multirow{4}{*}{ Perception of Interest Rate $\left(\xi_{1 c}\right)$} & $x_{11 c}$ & 0,913 & Valid \\
\hline & & $x_{12 c}$ & 0,757 & Valid \\
\hline & & $x_{13 c}$ & 0,826 & Valid \\
\hline & & $x_{14 c}$ & 0,908 & Valid \\
\hline \multirow{4}{*}{3.} & \multirow{4}{*}{ Perception of IPI $\left(\xi_{2 c}\right)$} & $x_{21 c}$ & 0,702 & Valid \\
\hline & & $x_{22 c}$ & 0,925 & Valid \\
\hline & & $x_{23 c}$ & 0,887 & Valid \\
\hline & & $x_{24 c}$ & 0,461 & Not Valid \\
\hline \multirow{4}{*}{4.} & \multirow{4}{*}{ Perception of Inflation $\left(\xi_{3 c}\right)$} & $x_{31 c}$ & 0,396 & Not Valid \\
\hline & & $x_{32 c}$ & 0,884 & Valid \\
\hline & & $x_{33 c}$ & $-0,027$ & Not Valid \\
\hline & & $x_{34 c}$ & 0,608 & Not Valid \\
\hline
\end{tabular}

In Table 5, it can be seen that the majority of the indicators of many research variables have an outer loading value of $>0.7$. However, some indicators have outer loading values $<0.7$, namely $x_{24 c^{\prime}}, x_{31 c^{\prime}} x_{33 c^{\prime}} x_{34 c^{\prime}}$. Therefore, these indicators and $\xi_{3 c}$ were removed from the model because $\xi_{3 c}$ only includes an indicator. The model was then reestimated by removing the arrow that has an outer loading below 0.7. 
The model structure includes four latent variables for the Islamic banks, consisting of one endogenous latent variable and three exogenous latent ones. In the conventional banking trust equation model, the endogenous variable is depositor trust. In contrast, the exogenous variable is the perception of the interest rate, of IPI, and of inflation. In the Islamic banking trust equation model, the variable is also depositor trust, while the exogenous variable is the perception of the profit sharing of Islamic banks, of IPI and of inflation. The endogenous latent variable and exogenous latent variable can be seen in Table 3 . The outer loading value results for all of the indicators are presented in Table 6.

Table 6.

Outer Loading Values of All of the Indicators for Islamic Banks

\begin{tabular}{|c|c|c|c|c|}
\hline No & Variable & Indicator & Outer Loading & Decision \\
\hline \multirow{8}{*}{1.} & \multirow{8}{*}{ Islamic Bank Depositor Trust $\left(\eta_{1 s}\right)$} & $y_{1 s}$ & 0,777 & Valid \\
\hline & & $y_{2 s}$ & 0,858 & Valid \\
\hline & & $y_{3 s}$ & 0,832 & Valid \\
\hline & & $y_{4 s}$ & 0,894 & Valid \\
\hline & & $y_{5 s}$ & 0,869 & Valid \\
\hline & & $y_{6 s}$ & 0,856 & Valid \\
\hline & & $y_{7 s}$ & 0,849 & Valid \\
\hline & & $y_{8 s}$ & 0,832 & Valid \\
\hline \multirow{4}{*}{2.} & \multirow{4}{*}{$\begin{array}{l}\text { Equivalent Yield Rate of Islamic } \\
\text { Banks }\left(\xi_{1 s}\right)\end{array}$} & $x_{11 \mathrm{~s}}$ & 0,961 & Valid \\
\hline & & $x_{125}$ & 0,352 & Not Valid \\
\hline & & $x_{13 s}$ & 0,371 & Not Valid \\
\hline & & $x_{145}$ & 0,707 & Valid \\
\hline \multirow{4}{*}{3.} & \multirow{4}{*}{ Perception of IPI $\left(\xi_{2 s}\right)$} & $x_{21 s}$ & 0,896 & Valid \\
\hline & & $x_{22 s}$ & 0,930 & Valid \\
\hline & & $x_{235}$ & 0,935 & Valid \\
\hline & & $x_{24 s}$ & 0,323 & Not Valid \\
\hline \multirow{4}{*}{4.} & \multirow{4}{*}{ Perception of IS $\left(\xi_{s 3}\right)$} & $x_{31 \mathrm{~s}}$ & 0,075 & Not Valid \\
\hline & & $x_{325}$ & $-0,455$ & Not Valid \\
\hline & & $x_{335}$ & 0,764 & Valid \\
\hline & & $x_{345}$ & $-0,302$ & Not Valid \\
\hline
\end{tabular}

In Table 6, it can be seen that the indicator of many research variables has an outer loading value of $>0.7$. However, several indicators that have an outer loading value of $<0.7$, namely $x_{12 s^{\prime}} x_{13 s^{\prime}} x_{24 s^{\prime}} x_{31 s^{\prime}}, x_{32 s^{\prime}} x_{34 s^{\prime}}$. Therefore, these indicators and $\xi_{3 s}$ were removed from the model because $\xi_{3 s}$ only includes an indicator. The model was then reestimated by removing the indicator with an outer loading below 0.7. 


\subsubsection{PLS-SEM Reestimation Results for Conventional Banks}

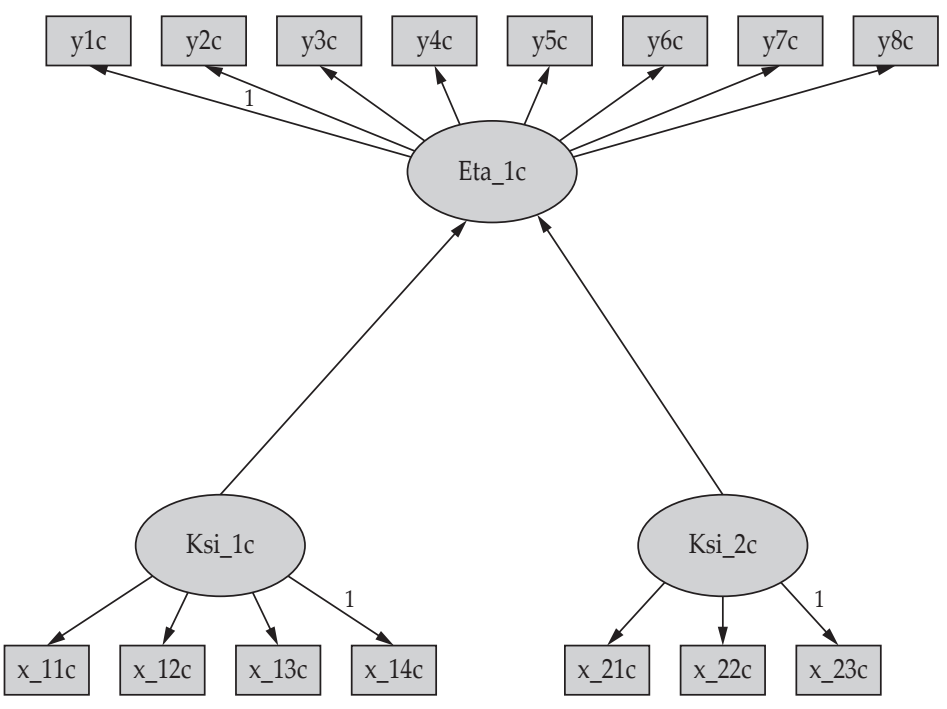

Figure 1.

Structural Model for the Conventional Bank Depositor Trust Model

The modeling of factors affecting the selection of conventional banks based on the PLS-SEM method was conducted by creating a path diagram, converting it into structural and measurement equations, and then estimating the parameters. The next step was to evaluate the model by observing the evaluation of the outer and inner models. Furthermore, analysis and interpretation of the structural model and measurement and assessment of the suitability of the overall model were performed using the Goodness of Fit criteria. The relationship between the variables is illustrated in Figure $\mathbf{1}$ based on the path diagram.

\subsubsection{Measurement Model Evaluation for Conventional Banks}

Table 7 shows the results of the outer loading after reestimation, demonstrating that each indicator of the research variables has met the requirements, which is $\geq$ 0.7. Therefore, there was no need to reestimate the outer loading process. 
Table 7.

Outer Loading Values after Reestimation of the Conventional Banks

\begin{tabular}{|c|c|c|c|c|}
\hline No & Variable & Indicator & Outer Loading & Decision \\
\hline \multirow{8}{*}{1.} & \multirow{8}{*}{$\begin{array}{c}\text { Conventional Bank Depositor } \\
\text { Trust }\left(\eta_{1 c}\right)\end{array}$} & $y_{1 c}$ & 0,819 & Valid \\
\hline & & $y_{2 c}$ & 0,880 & Valid \\
\hline & & $y_{3 c}$ & 0,818 & Valid \\
\hline & & $y_{4 c}$ & 0,868 & Valid \\
\hline & & $y_{5 c}$ & 0,875 & Valid \\
\hline & & $y_{6 c}$ & 0,870 & Valid \\
\hline & & $y_{7 c}$ & 0,818 & Valid \\
\hline & & $y_{8 c}$ & 0,802 & Valid \\
\hline \multirow{4}{*}{2.} & \multirow{4}{*}{ Perception of Interest Rate $\left(\xi_{1 c}\right)$} & $x_{11 c}$ & 0,913 & Valid \\
\hline & & $x_{12 c}$ & 0,757 & Valid \\
\hline & & $x_{13 c}$ & 0,826 & Valid \\
\hline & & $x_{14 c}$ & 0,908 & Valid \\
\hline \multirow{3}{*}{3.} & \multirow{3}{*}{$\begin{array}{l}\text { Perception of Industry } \\
\text { Productivity Index }\left(\xi_{2 c}\right)\end{array}$} & $x_{21 c}$ & 0,717 & Valid \\
\hline & & $x_{22 c}$ & 0,926 & Valid \\
\hline & & $x_{235}^{25}$ & 0,885 & Valid \\
\hline
\end{tabular}

Another method used to check the value of convergent validity is to evaluate the Average Variance Extracted (AVE) of each latent variable. According to Santosa (2018), the AVE value should be $\geq 0.5$ to ensure that each variable has convergent validity worth using. The AVE values obtained through the software are shown in Table 8 , in which it can be seen that all the variables have an AVE value of $\geq 0.5$, so meet the validity.

Table 8.

Validity Test Results on AVE for Conventional Banks

\begin{tabular}{lcc}
\hline Variable & AVE & Result \\
\hline Conventional Bank Depositor Trust $\left(\eta_{1 c}\right)$ & 0.713 & Valid \\
Perception of Interest Rate $\left(\xi_{1 c}\right)$ & 0.728 & Valid \\
Perception of IPI $\left(\xi_{2 c}\right)$ & 0.718 & Valid \\
\hline
\end{tabular}

The next step in evaluating the measurement model is to assess the discriminant validity by observing the cross-loading value. The cross-loading criterion for each indicator measuring its construct must have a higher correlation with the latent variable than the other latent variables. Table 9 shows the cross-loading value of each indicator. 
Table 9.

Cross Loading Values of Conventional Banks

\begin{tabular}{llccc}
\hline & & $\begin{array}{c}\text { Motivation of Conventional } \\
\text { Bank Customers }\end{array}$ & IPI & Interest rate \\
\hline \multirow{3}{*}{$\begin{array}{l}\text { Perception of Interest } \\
\text { Rate }\left(\xi_{1 c}\right)\end{array}$} & $x_{11 c}$ & 0,271 & 0,261 & 0,913 \\
\cline { 2 - 5 } & $x_{12 c}$ & 0,072 & 0,204 & 0,757 \\
\cline { 2 - 5 } & $x_{13 c}$ & 0,138 & 0,205 & 0,826 \\
\hline \multirow{2}{*}{$\begin{array}{l}x_{14 c} \\
\left(\xi_{2 c}\right)\end{array}$} & $x_{21 c}$ & 0,202 & 0,211 & 0,908 \\
\hline & $x_{22 c}$ & 0,293 & 0,717 & 0,071 \\
\cline { 2 - 5 } & $x_{23 c}$ & 0,511 & 0,926 & 0,231 \\
\cline { 2 - 5 } & $y_{1 c}$ & 0,534 & 0,885 & 0,304 \\
\cline { 2 - 5 } $\begin{array}{l}\text { Conventional Bank } \\
\text { Depositor Trust } \\
\left(\eta_{1 c}\right)\end{array}$ & $y_{2 c}$ & 0,819 & 0,500 & 0,272 \\
\cline { 2 - 5 } & $y_{3 c}$ & 0,880 & 0,578 & 0,244 \\
\cline { 2 - 5 } & $y_{4 c}$ & 0,818 & 0,319 & 0,158 \\
\cline { 2 - 5 } & $y_{5 c}$ & 0,868 & 0,450 & 0,152 \\
\cline { 2 - 5 } & $y_{6 c}$ & 0,875 & 0,478 & 0,146 \\
\hline & $y_{7 c}$ & 0,870 & 0,371 & 0,165 \\
\hline & $y_{8 c}$ & 0,818 & & 0,205 \\
\hline
\end{tabular}

Based on the data presented in Table 9, it can be seen that each indicator in the research variable has a very high cross-loading value on its latent variable compared to that for the other variables. From the results, it can be stated that the indicators used in this study have good discriminant validity in compiling their respective variables.

The next step in evaluating the measurement model is to test the reliability, which shows the accuracy, consistency, and accuracy of an instrument in making measurements. The reliability test can use the composite reliability method and Cronbach's alpha, each of which has a value of $\geq 0,7$. Table 9 shows the output results, which include the composite reliability and Cronbach's alpha of the latent variables.

Table 10

Composite Reliability and Cronbach's Alpha of Conventional Banks

\begin{tabular}{lccl}
\hline Variable & $\begin{array}{c}\text { Composite } \\
\text { Reliability }\end{array}$ & Cronbach's Alpha & Result \\
\hline Conventional Bank Depositor Trust $\left(\eta_{1 c}\right)$ & 0.952 & 0.713 & Reliable \\
Perception of Interest Rate $\left(\xi_{1 c}\right)$ & 0.914 & 0.728 & Reliable \\
Perception of IPI $\left(\xi_{2 c}\right)$ & 0.883 & 0.718 & Reliable \\
\hline
\end{tabular}

The results shown in Table 10 contain three latent variables, each with composite reliability and Cronbach's alpha values of $\geq 0,7$. Therefore, it can be concluded that the model is reliable. Furthermore, the analysis of the structural model testing can continue. 


\subsubsection{Structural Model Evaluation for Conventional Banks}

Evaluation of structural models can be performed to ensure that they have been built accurately; the analysis can be made using the coefficient of determination. A better coefficient of determination value $\left(R^{2}\right)$ implies a greater influence of the exogenous latent variables on the endogenous variables. The $\mathrm{R}^{2}$ is only owned by the endogenous variables. For conventional banks generated $R^{2}$ for endogenous variables of 0.808 . This indicates that $80.8 \%$ of the variation in the latent variables, namely conventional banks, can be explained by the exogenous latent variables of interest rates and IPI.

\subsubsection{Hypothesis Testing for Conventional Banks}

Hypothesis testing was also conducted, which aimed to determine the effect of the indicators on the exogenous variables (outer model) and of the exogenous latent variables on endogenous latency (inner model). The path coefficient and t-statistic values used to test the statistical hypothesis on the structural model were obtained through the bootstrapping process. The processing results for estimating the inner model parameters are summarised in Table 11.

Table 11.

Output Path Coefficient for Conventional Banks

\begin{tabular}{|c|c|c|c|c|}
\hline Variable & $\begin{array}{c}\text { Original } \\
\text { Sample (O) }\end{array}$ & $\begin{array}{l}\text { Sample Mean } \\
\text { (M) }\end{array}$ & $\begin{array}{l}\text { Standard } \\
\text { Deviation } \\
\text { (STDEV) }\end{array}$ & $\begin{array}{l}\text { T Statistics }(\mid \mathrm{O} / \\
\text { STDEV } \mid)\end{array}$ \\
\hline $\begin{array}{l}\text { IPI -> Conventional Bank } \\
\text { Depositor Trust }\end{array}$ & 0.522 & 0.530 & 0.051 & 10,212 \\
\hline $\begin{array}{l}\text { Interest Rate -> Conventional } \\
\text { Bank Depositor Trust }\end{array}$ & 0.695 & 0.704 & 0.050 & 17,721 \\
\hline
\end{tabular}

Statistical hypothesis testing was conducted using a significance level of $\alpha=5 \%$ and obtained t-table=1.97. Based on the results of the analysis shown in Table 10, the interpretation of the inner model hypothesis test results is as follows:

a. $\mathrm{H}_{0}: \gamma_{11 \mathrm{c}}=0$ (the interest rate variable $\left(\xi_{1 \mathrm{c}}\right)$ does not significantly influence conventional bank customer motivation $\left(\eta_{1 \mathrm{c}}\right)$ )

$\mathrm{H}_{0}: \gamma_{11 \mathrm{c}} \neq 0$ (the interest rate variable $\left(\xi_{1 \mathrm{c}}\right)$ significantly influences conventional bank customer motivation $\left.\left(\eta_{1 c}\right)\right)$

With reference to Table 11, a t-statistic value of 17,721 was obtained. Because the value of $t_{\text {statistic }}=17,721>t_{\text {table }}=1,97$, the decision is to reject $H_{0}$. This means that the interest rate variable $\left(\xi_{1 \mathrm{c}}\right)$ significantly influences conventional bank customer motivation $\left(\eta_{1 \mathrm{c}}\right)$

b. $H_{0}: \gamma_{12 c}=0$ (the IPI variable $\left(\xi_{2 c}\right)$ does not significantly influence conventional bank customer motivation $\left.\left(\eta_{1 c}\right)\right)$

$\mathrm{H}_{0}: \gamma_{12 c} \neq 0$ (the IPI variable $\left(\xi_{2 c}\right)$ significantly influences conventional bank customer motivation $\left(\eta_{1 \mathrm{c}}\right)$ ) 
Referring to Table 11, a t-statistic value of 10,212 was obtained. Because the value of $t_{\text {statistic }} 10,212>t_{\text {table }} 1,97$, the decision is to reject $H_{0}$. This means that the variable of IPI $\left(\xi_{2 c}\right)$ significantly influences conventional bank customer motivation $\left(\eta_{1 \mathrm{c}}\right)$

\subsubsection{Estimation Results for Conventional Banks}

The final form of the structural equation from the path diagram in Figure is presented in equation (6) as follows:

$$
\hat{\eta}_{1 \mathrm{c}}=-0,095 \xi_{1 \mathrm{c}}+0,552 \xi_{2 \mathrm{c}}
$$

The interpretation is that if there is a change in customer perception due to an increase in interest rates, there will be a decrease in conventional bank customers' motivation by 0.095 units. If there is a change in customers' perception due to an increase in IPI, there will be an increase in conventional bank customers' motivation by 0.552 units.

\subsubsection{PLS-SEM Reestimation Results for Islamic Banks}

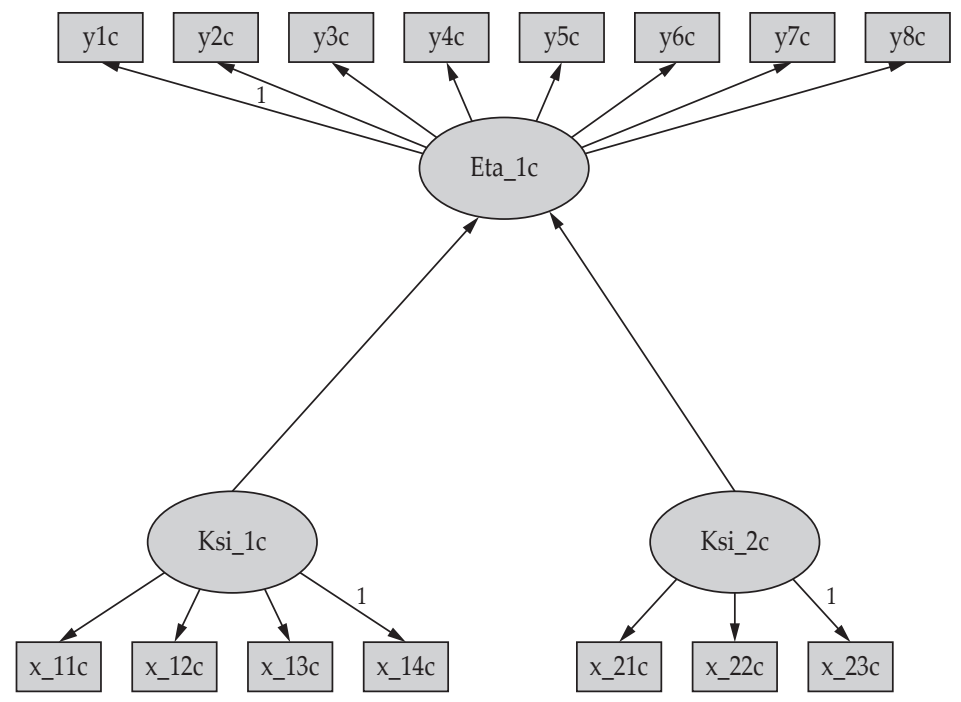

Figure 2.

Structural Model for Islamic Bank Depositor Trust Model

The modeling of factors affecting the selection of Islamic banks based on the PLS-SEM method was performed by creating a path diagram, converting it into structural and measurement equations, and estimating the parameters. The next step was to evaluate the model by observing the evaluation of the outer 
and inner models. Furthermore, analysis and interpretation of the structural model and measurement and assessment of the suitability of the overall model were conducted using the Goodness of Fit criteria. The relationship between the variables is illustrated based on the path diagram in Figure 2.

\subsubsection{Measurement Model Evaluation for Islamic Banks}

Table 12 results from outer loading after reestimation, showing that each indicator of the research variable has met the requirement, which is $\geq 0,7$. Therefore, there is no need to re-estimate the outer loading process.

Table 12.

Islamic Bank Outer Loading Values after Reestimation

\begin{tabular}{|c|c|c|c|c|}
\hline No & Variable & Indicator & Outer Loading & Decision \\
\hline \multirow{8}{*}{1.} & \multirow{8}{*}{$\begin{array}{l}\text { Islamic Bank Depositor Trust } \\
\qquad\left(\eta_{1 s}\right)\end{array}$} & $y_{1 s}$ & 0,784 & Valid \\
\hline & & $y_{2 s}$ & 0,862 & Valid \\
\hline & & $y_{3 s}$ & 0,831 & Valid \\
\hline & & $y_{4 s}$ & 0,893 & Valid \\
\hline & & $y_{5 s}$ & 0,867 & Valid \\
\hline & & $y_{6 s}$ & 0,850 & Valid \\
\hline & & $y_{7 \mathrm{~s}}$ & 0,845 & Valid \\
\hline & & $y_{8 s}$ & 0,831 & Valid \\
\hline \multirow{2}{*}{2.} & \multirow{2}{*}{$\begin{array}{l}\text { Equivalent Yield Rate of } \\
\text { Islamic Banks }\left(\xi_{1 s}\right)\end{array}$} & $x_{11 s}$ & 0,961 & Valid \\
\hline & & $x_{14 s}$ & 0,706 & Valid \\
\hline \multirow{3}{*}{3.} & \multirow{3}{*}{ Perception of IPIs $\left(\xi_{2 s}\right)$} & $x_{21 s}$ & 0,895 & Valid \\
\hline & & $x_{22 s}$ & 0,930 & Valid \\
\hline & & $x_{23 s}$ & 0,935 & Valid \\
\hline
\end{tabular}

Table 13.

Validity Test Results based on AVE for Islamic Banks

\begin{tabular}{lcc}
\hline Variable & AVE & Result \\
\hline Islamic Bank Depositor Trust $\left(\eta_{1 s}\right)$ & 0,716 & Valid \\
Equivalent Yield Rate of Islamic Banks $\left(\xi_{1 s}\right)$ & 0,711 & Valid \\
Perception of IPIs $\left(\xi_{25}\right)$ & 0,847 & Valid \\
\hline
\end{tabular}


Table 14.

Cross Loading Values of Islamic Banks

\begin{tabular}{llccc}
\hline & & $\begin{array}{c}\text { Motivation of } \\
\text { Islamic Bank } \\
\text { Customers }\end{array}$ & IPI & $\begin{array}{c}\text { Sharing } \\
\text { Profit }\end{array}$ \\
\hline $\begin{array}{l}\text { Equivalent Yield Rate of } \\
\text { Islamic Banks }\left(\xi_{15}\right)\end{array}$ & $x_{11 s}$ & 0,314 & 0,177 & 0,961 \\
\hline \multirow{2}{*}{$\begin{array}{l}\text { Perception of IPIs } \\
\left(\xi_{2 s}\right)\end{array}$} & $x_{14 s}$ & 0,122 & 0,120 & 0,706 \\
\hline & $x_{21 s}$ & 0,294 & 0,895 & 0,059 \\
\cline { 2 - 5 } & $x_{22 s}$ & 0,321 & 0,930 & 0,221 \\
\cline { 2 - 5 } & $x_{23 s}$ & 0,331 & 0,935 & 0,209 \\
\cline { 2 - 5 } & $y_{1 s}$ & 0,784 & 0,249 & 0,375 \\
\cline { 2 - 5 } $\begin{array}{l}\text { Islamic Bank Depositor Trust } \\
\left(\eta_{15}\right)\end{array}$ & $y_{2 s}$ & 0,862 & 0,271 & 0,330 \\
\cline { 2 - 5 } & $y_{3 s}$ & 0,831 & 0,222 & 0,236 \\
\cline { 2 - 5 } & $y_{4 s}$ & 0,893 & 0,271 & 0,223 \\
\cline { 2 - 5 } & $y_{5 s}$ & 0,867 & 0,343 & 0,180 \\
\cline { 2 - 5 } & $y_{6 s}$ & 0,850 & 0,322 & 0,135 \\
\cline { 2 - 5 } & $y_{7 s}$ & 0,845 & 0,271 & 0,157 \\
\hline & $y_{8 s}$ & 0,831 & 0,353 & 0,278 \\
\hline
\end{tabular}

Another method used to check the value of convergent validity is to evaluate the Average Variance Extracted (AVE) of each latent variable. According to Santosa (2018), the AVE value should be $\geq 0.5$ to ensure that each variable has convergent validity worth using. The AVE values obtained through software can be seen in Table 12, in which it is shown that all the variables have values of $\geq 0.5$ so meet the validity.

The next step in evaluating the measurement model is to assess discriminant validity by observing the cross-loading values. The cross-loading criterion for each indicator measuring its construct must have a higher correlation with the latent variable than the other latent variables. The following is the cross-loading value of each needle:

Based on the data presented in Table 13, it can be seen that each indicator in the research variable has the highest cross-loading value on its latent variable compared to that on the other variables. Based on the results obtained, it can be stated that the indicators used in this study have good discriminant validity in compiling their respective variables.

The next step in evaluating the measurement model is to test its reliability. Reliability shows the accuracy, consistency, and accuracy of an instrument in making measurements. The reliability test can use the composite reliability method and Cronbach's alpha, each of which has a value of $\geq 0.7$. Table 14 shows the output results, which includes the composite reliability and Cronbach's alpha of the latent variables. 
Table 15.

Composite Reliability and Cronbach's Alpha for Islamic Banks

\begin{tabular}{lcl}
\hline Variable & $\begin{array}{c}\text { Composite } \\
\text { Reliability }\end{array}$ & Result \\
\hline Islamic Bank Depositor Trust $\left(\eta_{15}\right)$ & 0,953 & Reliable \\
Equivalent Yield Rate of Islamic Banks $\left(\xi_{1 s}\right)$ & 0,828 & Reliable \\
Perception of IPIs $\left(\xi_{25}\right)$ & 0,943 & Reliable \\
\hline
\end{tabular}

Table 14 contains three latent variables each with composite reliability and Cronbach's alpha values of $\geq 0.7$. It can thus be concluded that the model formed is reliable and analysis of the structural model testing can continue.

\subsubsection{Structural Model Evaluation for Islamic Banks}

Evaluation of the structural models can be used to ensure that their build is accurate. Structural model analysis can be performed using the coefficient of determination. A higher value $\left(R^{2}\right)$ implies a greater influence of the exogenous latent variables on the endogenous variables. The $\mathrm{R}^{2}$ is only owned by endogenous variables. For Islamic banks the generated $\mathrm{R}^{2}$ for endogenous variables of 0.773 . This value indicates that $77.3 \%$ of the variation in the latent variables, namely Islamic banks, can be explained by the exogenous latent variables of interest rates and IPI.

\subsubsection{Hypothesis Testing for Islamic Banks}

Hypothesis testing was also conducted, with the aim to determine the effect of the indicators on the exogenous variables (outer model) and of the exogenous latent variables on endogenous latency (inner model). The path coefficient and t-statistic values used to test the statistical hypothesis on the structural model were obtained through the bootstrapping process. The processing results for estimating the inner model parameters are summarised in Table $\mathbf{1 6 .}$

Table 16.

Output Path Coefficients for Islamic Banks

\begin{tabular}{|c|c|c|c|c|}
\hline Variable & $\begin{array}{l}\text { Original } \\
\text { Sample (O) }\end{array}$ & $\begin{array}{l}\text { Sample } \\
\text { Mean (M) }\end{array}$ & $\begin{array}{l}\text { Standard } \\
\text { Deviation } \\
\text { (STDEV) }\end{array}$ & $\begin{array}{c}\text { T Statistics }(\mid \mathrm{O} / \\
\text { STDEV } \mid)\end{array}$ \\
\hline $\begin{array}{l}\text { Perception of IPI -> Islamic Bank } \\
\text { Depositors Trust }\end{array}$ & 0,300 & 0,301 & 0,095 & 3,165 \\
\hline $\begin{array}{l}\text { Equivalent of Yield Rate Islamic } \\
\text { Bank -> Islamic Bank }\end{array}$ & 0,238 & 0,251 & 0,069 & 3,457 \\
\hline
\end{tabular}

The statistical hypothesis testing was performed using a significance level of $\alpha=5 \%$ and obtained t-table=1.97. Based on the results of the analysis shown in Table 15, the interpretation of the inner model hypothesis test results is as follows. 
a. $H_{0}: \gamma_{11 s}=0$ (the equivalent yield rate of Islamic banks variable $\left(\xi_{1 s}\right)$ does not have a significant effect on Islamic bank customer motivation $\left(\eta_{1 s}\right)$ )

$H_{0}: \gamma_{11 s} \neq 0$ (the equivalent yield rate of Islamic banks variable $\left(\xi_{1 s}\right)$ significantly influences Islamic bank customer motivation $\left(\eta_{1 s}\right)$ )

As shown in Table 16, a t-statistic value of 3,457 was obtained. Because the value of $t_{\text {statistic }}=3,457>t_{\text {table }}=1,97$; therefore the decision was to reject $H_{0}$, meaning that the profit sharing $\left(\xi_{1 s}\right)$ variable significantly influences Islamic bank customer motivation $\left(\eta_{1 s}\right)$

b. $H_{0}: \gamma_{12 s}=0$ (the IPI variable $\left(\xi_{2 s}\right)$ does not have a significant effect on Islamic bank customer motivation $\left.\left(\eta_{1 s}\right)\right)$

$H_{0}: \gamma_{12 s} \neq 0$ (the IPI variable $\left(\xi_{2 s}\right)$ significantly influences Islamic bank customer motivation $\left.\left(\eta_{1 s}\right)\right)$

Table 16 shows that a t-statistic value of 3,165 was obtained. Because the value of $\mathrm{t}_{\text {statistic }}=3,165>\mathrm{t}_{\text {table }}=1,97$, the decision was to reject $H_{0^{\prime}}$ which means that the IPI variable $\left(\xi_{2 s}\right)$ significantly influences Islamic bank customer motivation $\left(\eta_{1 s}\right)$.

\subsubsection{Estimation Results for Islamic Banks}

The final form of the structural equation from the path diagram in Figure 6 is presented in equation (7):

$$
\hat{\eta}_{1 \mathrm{~s}}=0,238 \xi_{1 \mathrm{~s}}+0,300 \xi_{2 \mathrm{~s}}
$$

It is interpreted that if there is a change in customer perception due to an increase in profit sharing, there will be an increase in Islamic bank customers' motivation of 0.238 units. If there is a change in customer perception due to a rise in IPI, there will be an increase in Islamic bank customer motivation by 0.300 units.

\subsection{Analysis and Discussion Perception of Interest Rates}

The PLS model findings are not in line with those of Widowati \& Mustikawati (2018), who found that that the perception of reasonable interest rates adversely affected the intention to save in conventional banks. The findings of this study are also inconsistent with those of Rini \& Mustikawati (2019), who found that customers' perceptions of interest rates significantly affected their desire to save in state-owned banks in Rejowinangun. Similarly, the PLS model findings are different to those of Sumolang (2019), who demonstrated that farmers in Indonesia with savings claimed to be satisfied with the interest rates earned at Indonesian commercial banks.

This finding was confirmed by the respondents' answers to the conventional bank interest rate questions. The majority, 54.5\%, indicated that they strongly disagreed that their reason for saving at conventional banks was attractive interest rates. In the interest rate question group, most respondents $(51.2 \%)$ indicated that they strongly disagreed with the statement that they made withdrawals from 
conventional banks when the interest rate decreased. Most of the respondents, $46.9 \%$, also indicated that they strongly disagreed that they would not open a conventional bank deposit account if the interest rate were too low.

Another reason why conventional bank interest is not a dominant reason for customers to save funds in conventional banks is reflected in the respondents' answers given in the data description in Chapter 4 . The majority of respondents chose to use conventional banks because they were paid higher salaries. Reached the largest number, namely $131.40 \%$, then followed by incentive payments at $51.15 \%$, followed by guaranteed deposit institutions, security for deposit funds, and bank reputation, which each scored $49.15 \%$.

\section{Perception of Equivalent Yield Rate of Islamic Banks}

The PLS model results show an effect of the equivalent yield rate of Islamic banks on the saving behaviour in Islamic banks. This finding is in line with the results of Risal and Alexander's (2019) analysis. Their study revealed an $\mathrm{R}^{2}$ number of 0.413 , which means that the equivalent yield rate of Islamic banks could explain $41.3 \%$ of the changes in the decision variable related to the use of Islamic banking services for mudharabah savings for customers in Medan, North Sumatra. This finding is also in line with Hutagalung's (2017) analysis, which provides evidence of the effect of perceptions of the equivalent yield rate of Islamic banks on interest in becoming a customer of Islamic banks in Medan, North Sumatra. The SEMPLS model analysis results are also in line with the research results of Hariadi \& Angriani (2018), which showed an effect of the equivalent yield rate of Islamic bank perceptions on interest in saving at Islamic banks in the city of Surabaya, East Java.

This finding can be confirmed by the respondents' answer to the question on the level of the equivalent yield rate of Islamic banks. As stated in the data description in Chapter 4, most respondents, namely $41.2 \%$, agreed that the reason for saving funds in Islamic banks was because there was a fair equivalent yield rate. The highest number of respondents, $46.4 \%$, disagreed that they would withdraw their Islamic bank savings if this rate fell.

\section{Perception of IPI}

The PLS model analysis results show a significant positive effect of the industrial production index on the interest in saving in Islamic banks. This finding is in line with the respondents' answers; the majority, 68.7\%, agreed that if the IPI number increased, it would increase their interest in making savings in conventional banks. In the Islamic bank category, the figure was $66.3 \%$.

\section{Perception of Inflation}

The PLS model analysis results show no significant positive effect of inflation on interest in saving. This finding contradicts the study of Putri (2019), who concluded that the perception of inflation influenced interest in saving at Islamic banks in the city of Padang Sidempuan. This finding is also different to those of Guntara (2020), who found that inflation had an effect on interest in saving at conventional banks in Medan.

This finding is in line with the respondents' answers, as discussed in Chapter 4. The majority of respondents, $44.6 \%$, disagreed that if inflation were low, they would decide to save funds. As for Islamic banks, $48.4 \%$ of respondents disagreed that high inflation would make them withdraw funds. 
Comparison of the Effects of Interest and Profit Sharing on Bank Customer Trust Explanation of the comparison between the role of interest and profit sharing in bank customers' trust. Based on the results of the study, it was found that interest rates did not affect conventional bank customers' trust. It is better if the profit-sharing of an Islamic bank affects the trust of Islamic bank customers. This issue emerges amongst customers who have two types of bank account (that is, the respondents of this study). Islamic teachings prohibit interest, so Muslim customers have no choice but to avoid banks. In contrast, profit sharing for Muslim customers indicates how Islamic banks have implemented Islamic principles well and how the banks manage their business.

\section{CONCLUSION AND RECOMMENDATION}

\subsection{Conclusion}

Based on the research objectives and considering the results and discussion, it is concluded that by using primary data, there is an influence of internal factors, namely bank interest, and external factors, namely IPI, as representations of national economic conditions affecting customer trust. This is one of the assets that influences the amount of depositor funds in conventional banks, to keep qualitatively using conventional banks during the COVID-19 pandemic based on the PLS method. Other external factors, such as inflation, do not affect the trust of conventional bank customers.

By using primary data, there is an influence of internal factors, namely profit-sharing, and external, namely IPI as a representation of national economic conditions on customer trust as an asset that affects the amount of DEPOSITOR FUNDS in Islamic banks, to continue to use Islamic banks during the COVID-19 pandemic qualitatively based on the PLS methods. Meanwhile, other external factors such as inflation do not affect customer confidence in Islamic banks.

\subsection{Recommendations}

This research provides input into policy consideration for three parties. The first party comprises the practitioners, such as conventional and Islamic bank managers. The second group is the regulators, namely Bank Indonesia, the Financial Services Authority, and the Deposit Insurance Corporation, and third parties are suggestions for further research.

\subsubsection{Recommendations for Practitioners Conventional Banks}

Conventional and Islamic banks are expected to provide the best performance to convince customers to maintain their savings with them. For banks, it is also necessary to a fair and attractive set of interests or equivalent yield rated of Islamic Banks. Based on the study results, these factors prove to be the determinants of bank customer trust. Banks also need to convey correct and useful information so that customers will be aware of their condition. This needs to be done because sufficient information will influence customer confidence. Conventional banks need to strive to maintain good governance according to government regulations in order to maintain customer confidence. 


\subsubsection{Recommendations for the Government and Regulators}

The study results can be used as a policy basis for how banking regulators in Indonesia can strive to maintain bank customers' trust in Indonesia. Regulators related to this research study include Bank Indonesia, the Financial Services Authority, the Deposit Insurance Corporation, the Financial System Stability Committee and the Ministry of Economic Affairs.

\section{Bank Indonesia}

Bank Indonesia, which is essential in maintaining inflation and exchange rates, plays a vital role in maintaining economists' confidence and persuading depositors to keep saving money in banks. Bank Indonesia is expected to be able to set a fair and attractive benchmark interest rate, which is an important reference for all banks in Indonesia.

\section{Financial Services Authority}

The Financial Services Authority, as a bank supervisor, plays a vital role in customer trust. The FSA should continue its role in promoting fair, standardised and transparent bank governance. This will have an impact on maintaining the trust of bank customers in Indonesia. A banking system with zero fraud and zero moral hazards will have a positive effect on customer confidence. The FSA needs to use law enforcement for troubled banks.

\section{Deposit Insurance Corporation}

The Deposit Insurance Corporation also plays a vital role in maintaining the trust of bank customers. This institution should continue to campaign for bank deposit insurance to the public. Guaranteeing the safety of customer funds is crucial for customer trust. Fund insurance campaigns could be run through the mass media and social media.

\section{Financial System Stability Committee}

Macroprudential and economic conditions are essential for bank customers. The role of the financial system stability committee in dealing with crisis risks needs to be continued. The committee should provide regular and routine information about economic conditions and how to take steps to mitigate the risk of crises.

\section{Ministry of Economic Affairs}

The ministry's role in the economic sector includes the authority to determine policies to advance the country's economy. Of course, this policy can affect the trust of bank customers. Therefore, the ministry should continue making policies that positively impact bank customers, such as tax and tariff regulations.

\subsubsection{Recommendations for Further Research}

Future studies should examine the determinants of the variables that have not been studied in this research. These include sharia compliance for Islamic banks, and sociodemographic factors such as education, occupation, location of residence, religion, income level, and gender, amongst others. Further research should also increase the number of respondents in order to represent the Indonesian people better. 


\section{REFERENCES}

Alamsyah, H., Ariefianto, M. D., Saheruddin, H., Wardono, S., \& Trinugroho, I. (2020). Depositors' trust: Some empirical evidence from Indonesia. Research in International Business and Finance, 54(December 2020), 101251. https:/doi. org/10.1016/j.ribaf.2020.101251.

Anbil, S. (2018). Managing stigma during a financial crisis. Journal of Financial Economics, 130(1), 166-181. https://doi.org/10.1016/j.jfineco.2017.05.014.

Ascarya. (2020). Nilai tukar dan pembangunan ekonomi [Exchange rates and economic development]. Presented in Webinar MES East Java dan IAEI East Java at 28 $8^{\text {th }}$ July 2020). Bank Indonesia, Islamic Economics Department Jakarta.

Avkiran, N., \& Ringle, C. (2018). Partial least squares structural equation modeling. Part of the International Series in Operations Research \& Management Science book series (ISOR, vol.267).

Azzara, C. V. (2010). Questionnaire design for business research: Beyond linear thinkingan interactive approach. Oklahoma: Tate Publishing.

Berggren, N., Daunfeldt, S. O., \& Hellström, J. (2014). Social trust and central-bank independence. European Journal of Political Economy, 34(June 2014), 425-439.

Chin, W. W. (1998). The partial least squares approach to structural equation modeling. In Marcoulides G. A. (Eds.), Modern Methods for Business Research. New York: Taylor \& Francis.

Chin, W. W. (2003). PLS graph 3.0. Houston: Soft Modeling Inc.

Fungáčová, Z., Hasan, I., \& Weill, L. (2019). Trust in banks. Journal of Economic Behavior \& Organization, 157(January 2019), 452-476.

Gadzo, S. G., Kportorgbi, H. K., \& Gatsi, J. G. (2019). Credit risk and operational risk on financial performance of universal banks in Ghana: A partial least squared structural equation model (PLS SEM) approach. Cogent Economics $\mathcal{E}$ Finance, 7(1), 1589406. https://doi.org/10.1080/23322039.2019.1589406.

Ghozali, I., \& Latan, H. (2015). Partial least squares, konsep, teknik dan aplikasi menggunakan program Smartpls 3.0 untuk penelitian empiris. Semarang: Badan Penerbit UNDIP.

Guntara, A. (2020). Pengaruh tingkat suku bunga dan inflasi terhadap minat menabung pada bank mandiri cabang balai Kota Medan [The effect of interest rates and inflation on interest saving at Mandiri Bank, branch of Medan City hall]. [Undergraduate Thesis]. Medan: Universitas Dharmawangsa.

Hair Jr, J. F., Sarstedt, M., Ringle, C. M., \& Gudergan, S. P. (2017). Advanced issues in partial least squares structural equation modeling. Los Angeles: Sage Publications.

Hariadi, S., \& Angriani, S. (2018). Pengaruh persepsi keyakinan dan bagi hasil terhadap minat menabung di bank syariah. Jurnal Ekonomi dan Bisnis, 23(1), 1-10.

Hidayat, S. E., Farooq, M. O, Nasution, A., \& Sari, C. A. (2020). COVID-19 and its impacts on the Islamic financial industry in the OIC countries [E-book]. In S. E. Hidayat, M. O. Farooq, \& E. A. Alim, (Eds.), Impacts of COVID-19 Outbreak on Islamic Finance in the OIC Countries (First ed., pp. 1-11). Jakarta: Komite Nasional Ekonomi dan Keuangan Syariah Republik Indonesia in Parnership with Dinar Standart and Salam Gateway. Retrieved from https://knks.go.id/ storage/upload/1591090473-b71788507b33ad61531b0705ed42b4269a8a994b. pdf. 
Hutagalung, M. A. K. (2019). Pengaruh kualitas pelayanan dan bagi hasil terhadap minat masyarakat menjadi nasabah bank syari'ah. Jurnal Al-Qasd Islamic Economic Alternative, 1(2), 228-239.

Jansen, D.-J., Mosch, R. H., \& van der Cruijsen, C. A. (2015). When does the general public lose trust in banks? Journal of Financial Services Research, 48(2), 127-141.

Jin, J. Y., Kanagaretnam, K., \& Wang, W. (2020). Societal trust and banks' funding structure. Journal of Behavioral and Experimental Finance, 27(September 2020), 100357. https://doi.org/10.1016/j.jbef.2020.100357.

Kartika, T., Firdaus, A., \& Najib, M. (2019). Contrasting the drivers of customer loyalty; financing and depositor customer, single and dual customer, in Indonesian Islamic bank. Journal of Islamic Marketing, 11(4), 933-959.

Knell, M., \& Stix, H. (2015). Trust in banks during normal and crisis timesevidence from survey data. Economica, 82(S1), 995-1020.

Kurlat, P. (2019). Deposit spreads and the welfare cost of inflation. Journal of Monetary Economics, 106(October 2019), 78-93.

Maulayati, R. R., Bahril, M. A., \& Herianingrum, S. (2020). Effect of macroeconomic variables on third-party funds in Islamic commercial banks in Indonesia. Journal of Islamic Economics Lariba, 6(1), 19-40.

Monecke, A., \& Leisch, F. (2012). SEMPLS: Structural equation modeling using partial least squares. Journal of Statistical Software, 48(3), 1-32.

Onyiriuba, L. (2016). Bank risk management in developing economies: Addressing the unique challenges of domestic banks. London: Academic Press.

Osili, U. O., \& Paulson, A. (2014). Crises and confidence: Systemic banking crises and depositor behavior. Journal of Financial Economics, 111(3), 646-660.

Otoritas Jasa Keuangan. (2020). Statistik perbankan syariah Indonesia [Indonesian sharia banking statistics]. Retrieved from www.ojk.go.id.

Park, N. Y. (2020). Trust and trusting behavior in financial institutions: Evidence from South Korea. International Review of Economics \& Finance, 67(May 2020), 408-419.

Putri, S. T. (2019). Pengaruh inflasi terhadap minat nasabah menabung di Bank Syariah Mandiri cabang Padangsidimpuan [The effect of inflation on customer interest in saving at Bank Syariah Mandiri, branch of Padangsidimpuan]. [Undergraduate Thesis]. Padang: IAIN Padangsidimpuan.

Rahman, M. A., Kusuma, A. Z., \& Arfyanto, H. (2020). Situasi ketenagakerjaan di lapangan usaha yang terdampak pandemi Covid-19 [The employment situation in the business field affected by the Covid-19 pandemic]. Catatan Isu Semeru, 1 Juni 2020, 01. Retrieved from https://www.smeru.or.id/sites/default/ files/publication/ib01_naker_id_0.pdf.

Rini, T. K., \& Mustikawati, R. I. (2019). Pengaruh persepsi nasabah mengenai lembaga penjamin simpanan (LPS), tingkat suku bunga, dan kualitas pelayanan terhadap minat menabung nasabah pada bank. Jurnal Profita: Kajian Ilmu Akuntansi, 7(4), 1-15.

Risal, T., \& Alexander, A. (2019). Pengaruh persepsi bagi hasil, promosi dan kualitas pelayanan terhadap minat penggunaan jasa perbankan syariah tabungan mudharabah pada mahasiswa universitas potensi utama. Jurnal Samudra Ekonomika, 3(2), 118-130. 
Santosa, P. I. (2018). Metode penelitian kuantitatif pengembangan hipotesis dan pengujiannya menggunakan SmartPLS. Yogyakarta: ANDI.

Sapienza, P., \& Zingales, L. (2012). A trust crisis. International Review of Finance, 12(2), 123-131.

Schoors, K., Semenova, M., \& Zubanov, A. (2019). Depositor discipline during crisis: Flight to familiarity or trust in local authorities? Journal of Financial Stability, 43(C), 25-39. 10.1016/j.jfs.2019.05.002.

Serrano-Cinca, C., Gutiérrez-Nieto, B., \& Molinero, C. M. (2011). Social and financial efficiency of microfinance institutions. In Armendariz, B \& Lable, M (Eds.), The Handbook of Microfinance (pp. 397-418). Singapore: World Scientific.

Situmorang, A. P. (2019, December 10). Per Oktober, OJK catat jumlah nasabah bank syariah capai 31,89 juta [As of October, OJK records the number of sharia bank customers to reach 31.89 million]. Retrieved from https:/www.merdeka.com/ uang/peroktober-ojk-catat-jumlah-nasabah-bank-syariah-capai-3189-juta. html.

Stevenson, B., \& Wolfers, J. (2011). Trust in public institutions over the business cycle. American Economic Review, 101(3), 281-87.

Sukmana, R., Indrawan, I. W., \& Ajija, S. R. (2020). The Impact of COVID-19 outbreak on the Islamic financial industry: Indonesia. In S. E. Hidayat, M. O. Farooq \& E. A. Alim (Eds.). Impacts of COVID-19 Outbreak on Islamic Finance in the OIC Countries. Jakarta: Komite Nasional Ekonomi dan Keuangan Syariah RI.

Sumolang, M. A., Rumagit, G. A. J., \& Pangemanan, L. R. J. (2019). Persepsi petani menabung di bank rakyat indonesia unit sonder. Agri-Sosioekonomi, 15(2), 299304.

Task Force for Handling COVID-19. (2020, September 25). Peta Pesebaran Covid 19 (Covid Distribution Map 19). Retrieved from https://covid19.go.id/peta-sebarancovid19.

Trujillo, G. S. (2009). Pathmox approach: Segmentation trees in partial least squares path modeling. Universitat Politècnica de Catalunya (UPC).

Ünvan, Y. A., \& Yakubu, I. N. (2020). Do bank-specific factors drive bank deposits in Ghana? Journal of Computational and Applied Mathematics, 376(October 2020), 112827. https://doi.org/10.1016/j.cam.2020.112827.

van Esterik-Plasmeijer, P. W. J, \& Van Raaij, W. F. (2017). Banking system trust, bank trust, and bank loyalty. International Journal of Bank Marketing, 35(1), 97111. https://doi.org/10.1108/IJBM-12-2015-0195.

Widowati, A. S., \& Mustikawati, R. I. (2018). Pengaruh pengetahuan produk tabungan, reputasi bank, dan persepsi nasabah mengenai suku bunga simpanan terhadap keputusan menabung nasabah. Nominal: Barometer Riset Akuntansi dan Manajemen, 7(2), 141-156.

World Health Organizations, \& W.H.O. (2020, September 1). WHO Corona Virus Disease (COVID-19) Dashboard. Https://Www.Who.Int/. https://covid19.who. int/. 